\title{
Improvement of Private Pension System in Turkey and Measurement of Its Efficiency with DEA
}

\author{
Ahmet Kurtaran ${ }^{1}$, Aykut Karakaya ${ }^{1} \&$ Hüseyin Dağl $1^{1}$ \\ ${ }^{1}$ Department of Business Administration, Karadeniz Technical University, Trabzon, Turkey \\ Correspondence: Ahmet Kurtaran, Department of Business Administration, Karadeniz Technical University, \\ Trabzon, Turkey. Tel: 90-462-377-8779. E-mail: kurtaran@ktu.edu.tr
}

Received: August 29, 2013

Accepted: October 14, $2013 \quad$ Online Published: October 26, 2013

doi:10.5539/ijef.v5n11p163

URL: http://dx.doi.org/10.5539/ijef.v5n11p163

\begin{abstract}
The aim of this study is to analyze improvement of private pension system in Turkey in numerical quantities according to years and measure efficiency of system. Data envelopment analysis (DEA) was used as measurement method in the study. Inputs of DEA model are the number of employees and total assets. Total quantity of total premiums and funds is the output of model. The study is original since it differentiates pension companies as large-small scaled and domestic-foreign ones and enables more detailed analysis about efficiency. When analysis results are considered, it was observed that efficiency level in system had normal course with slight changes in the last 6 years. It was also concluded that large-scaled company group had lower efficiency than small-scaled company group and domestic companies had lower efficiency than foreign companies. The main reason of inefficiency was their inability to operate in optimal scale due to financial crisis.
\end{abstract}

Keywords: DEA, efficiency analysis, private pension system

\section{Introduction}

The weight of private pension system (PPS) within financial sector increases and therefore it has become quite important for private pension companies which are the actors of system to be managed well and use their resource efficiently. According to OECD statistics, pension fund assets all over the world are USD 20.1 trillion in 2011. The OECD weighted average asset-to-gross domestic product (GDP) ratio for pension funds reached $72.4 \%$ of GDP in 2011, with the Netherlands achieving the largest ratio in 2011, at $138 \%$. The importance of private pension systems can also be gauged by looking at the market value of assets accumulated relative to the size of the economy. The larger the value of their investments, the greater will be their ability to provide high benefits to individuals. In 2011, in relation to the national economy only three OECD countries achieved asset-to-GDP ratios higher than 100\%-the Netherlands (138\%), Iceland (129\%) and Switzerland (111\%). Considering generally, the average share of PPS within GDP in OECD countries is around 50\% (OECD, 2012). Thus, both the total net asset value of fund and their share within GDP show it clearly that PPS is quite important in the sense of economies.

Due to this importance, efficiency measurement of PPS and private pension companies in Turkey constitute the scope of this study. Efficiency measurement which is the scope of study was carried out with DEA method. In literature, DEA method is frequently used in studies where efficiency measurement of financial sector is done. However these studies are rather related with efficiency of banks and there are restricted number of studies about private pension companies.

For example, many researchers (Vassiloglou \& Giokas, 1990; Rangan et al., 1988, Yue, 1992; Fukuyama 1993; Favero \& Papi, 1995; Sherman \& Ladino, 1995; Lovell \& Pastor, 1997; Golany \& Storbeck, 1999; Dekker \& Post, 2001; Porembski et al., 2005 and Mansoury \& Salehi, 2011) studied about efficiency of banks with DEA. Also, Zaim (1995), Cingi \& Tarım (2000), Denizer et al., (2000), Mercan et al., (2003), Işık et al., (2003) have studied DEA on Turkish banking sector. Moreover, some scholars (Cummins et al., 1999; Yang, Z., 2006; Wu et al., 2007 and Kayalı, 2007) studied related to efficiency measurement of insurance companies that are financial institutions except for banks.

In addition, there are some studies researching efficiency of private pension companies in literature by using DEA. For example, Barrientos \& Boussofiane (2005), analyzed efficiency of private pension companies in Chile. 
Also, while Barros \& Garcia, 2006 and Barros et al., 2008 focused Argentina companies, Teresa \& Garcia (2010) evaluated efficiency of Portugal pension funds management companies by using DEA-Malmquist index.

\section{Improvement of Private Pension System in Turkey}

In this section, improvement of PPS in Turkey by years is viewed from various aspects such as total value of fund, total assets and total premiums. Year of start of research period is 2004 because private pension companies in Turkey are active in 2003 year.

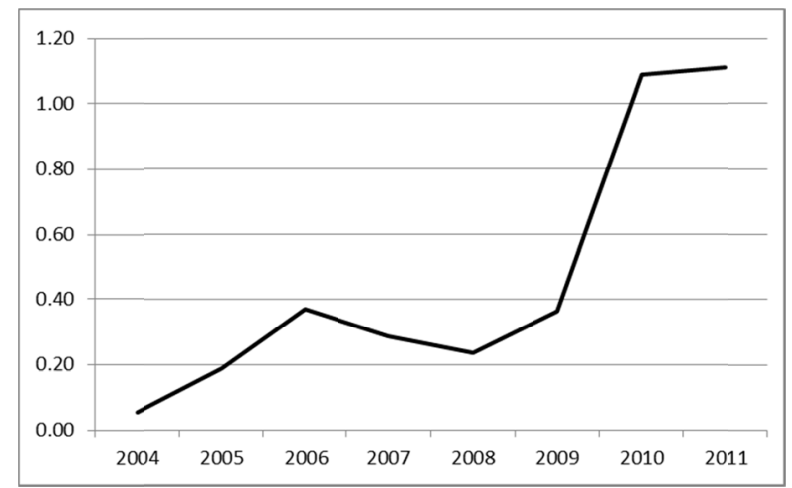

Figure 1. The share of total net asset value of fund within GDP by years (\%)

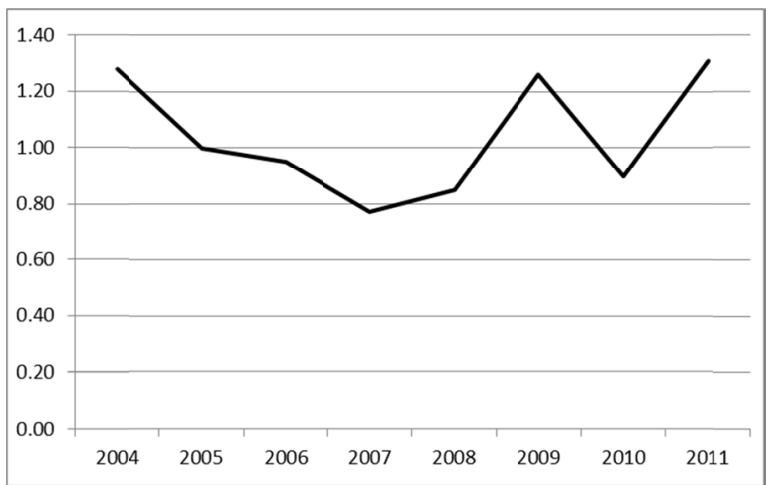

Figure 2. The share of amount of premiums within aggregate savings by years (\%)

Source: Figures are formed with data obtained from www.tuik.gov.tr and PPS improvement report.

The improvement of PPS during periods within the scope of study is presented in Figure 1 and 2. In Figure 1, the share of PPS funds within GDP is shown according to years. As it is seen in the figure, total net asset value of fund within GDP between 2004 and 2006 has increased however this situation has reversed between 2006 and 2008. The lowest rate was observed in 2008 and then with a swift increase, total net asset value of funds within GDP has increased above 1\% for the first time in 2010. The reason of decrease in 2006-2008 period results from decrease in fund value rather than increase in GDP. The reason of decrease in fund values is financial fluctuations experienced in the related period.

In Figure 2, the share of premium amounts in PPS within total savings is presented. Accordingly, while the share of private pension premiums within total savings was around $1.3 \%$ in 2004; it was observed that this rata decreased continuously until 2008 and then has a fluctuating course. This rate was at lowest level with $0.80 \%$ in 2007. The most prominent reason of decrease in rate of premiums to savings is the financial fluctuations. Due to financial fluctuations, decrease in both low level of saving and private pension premium which is the most important indicator of voluntary individual saving within savings increase problem of investment financing much more. It is compulsory to increase private pension premiums in order to increase domestic savings. If obtained premiums can be increased, then there would be less need for directing towards foreign resources with the aim of investment financing. 
Table 1. Basic statistical indicators about private pension system (Number/Million TRY)

\begin{tabular}{lrrrrrrrr}
\hline Variables & \multicolumn{1}{c}{ Years } \\
\cline { 2 - 9 } & 2004 & 2005 & 2006 & 2007 & 2008 & 2009 & 2010 & 2011 \\
\hline Number of Company & 11 & 11 & 11 & 10 & 11 & 13 & 13 & 14 \\
Foreign Companies & 1 & 2 & 2 & 2 & 5 & 7 & 8 & 8 \\
Number of Funds & 81 & 93 & 100 & 103 & 112 & 129 & 138 & 158 \\
Number of Employees & 7,961 & 8,911 & 5,610 & 6,171 & 6,291 & 5,922 & 6,024 & 6,549 \\
Number of Contracts & 349,011 & 376,491 & 482,839 & 391,816 & 168,843 & 434,491 & 331,302 & 403,540 \\
Equity $^{*}$ & 501 & 648 & 637 & 702 & 774 & 918 & 1,021 & 1,225 \\
Total Assets $^{*}$ & 3,824 & 4,916 & 5,841 & 7,098 & 8,058 & 10,170 & 11,331 & 11,964 \\
\hline
\end{tabular}

* Real values on the basis of 2004 according to producer price index. Source: www.treasury.gov.tr.

It is given statistical indicators about the improvement of PPS in Table 1. When PPS is considered generally according to statistical indicators; it is seen that licensed firms was at lowest level in 2007 being 10 in total and at highest level in 2011 being 14. While most of these firms were domestic firms before 2009, there were important increases in the number of foreign firms in following years. Although there is no serious increase in total number of firms the number of foreign firm increase which shows that the change is experienced within ownership structure of companies within sector. It is natural that the weight of foreigners in PPS increases continuously since we have young population as a country and the sector is promising due to the scarcity of companies. When the other indicators of sector which has high growth potential are considered, there is an increase in the number of funds which are the fields where savings are collected with premiums. This increase is greater than the increase in the number of companies. Companies put forward innovative choices in evaluation of savings in the sector. Due to high devaluation of TRY experienced in 2006 and global crisis which emerged in 2007 and became effective in 2008 and subsequent years in Turkey, the desired improvements did not happen in the number of employment and contracts of private pension companies. It is observed that stockholder's equity of companies was not influenced and capital structures of companies are. It is also seen that capital structure of companies is long lasting. The reason of that is foreign capital inflow and arrangements in financial section rather than internal dynamic of sector.

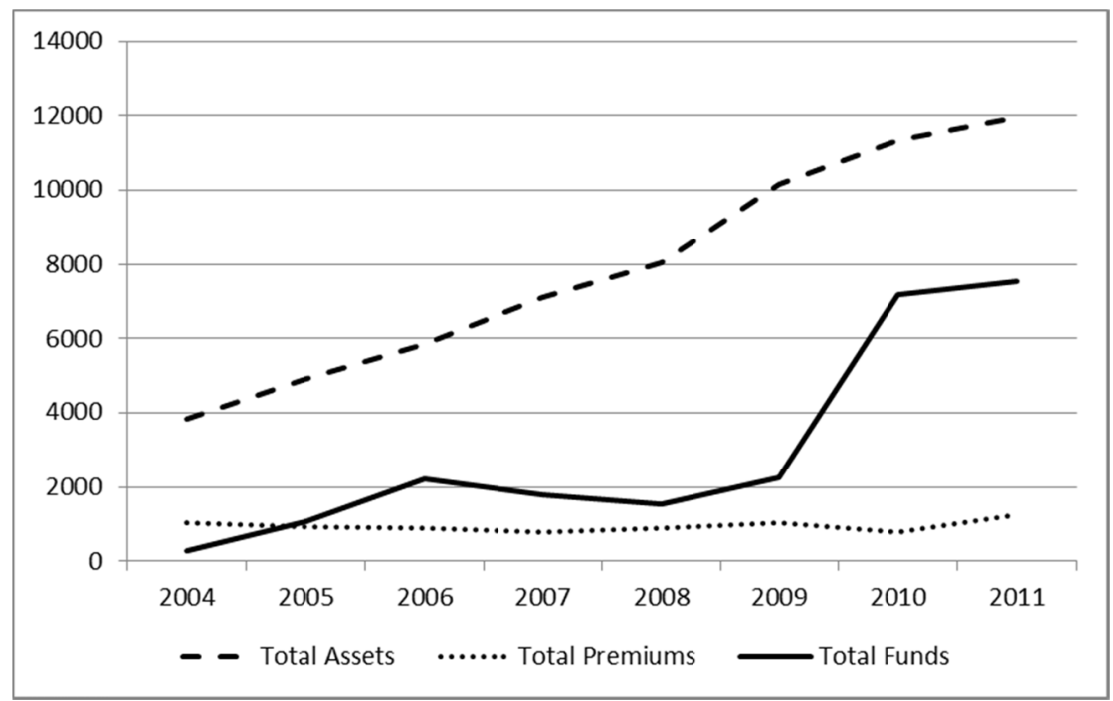

Figure 3. Numerical gratitude of private pension system by years (million TRY)

Source: www.treasury.gov.tr.

Figure 3 shows improvement of total value of funds in sector, premiums paid and total asset according to years. According to figure it is seen that total asset and total value of funds have increased significantly from 2004 to 2011. Especially total assets have increased regularly at each period. When, total net asset value of funds are considered, it is seen that it has increased regularly from 2004 to 2006 but it has not shown any improvement between 2006 and 2009 except for little decrease and increases. It has even reached the lowest value with 1.5 billion TRY in 2008 when global financial crisis is experienced. In addition to this, it has made an important leap 
between 2009 and 2010 and there was a growth rate in the last period which is far too greater than previous periods. Total funds reached approximately 7 billion TRY in this period. There is a quite different situation as for the amounts of paid premiums. Instead of increasing according to years, premiums have declines little by little. 1 billion TRY premium in 2004 declined to 785 million TRY in 2010 and reached the highest level with 1.3 billion TRY in 2011. Except for the unfavorable events experienced in macro level between 2006 and 2009, it is seen that pension companies can make high assets and fund values with low premiums. It would not be false to assert that the most important share in enabling this improvement with insufficient premiums should be given to innovative and competitive power of sector.

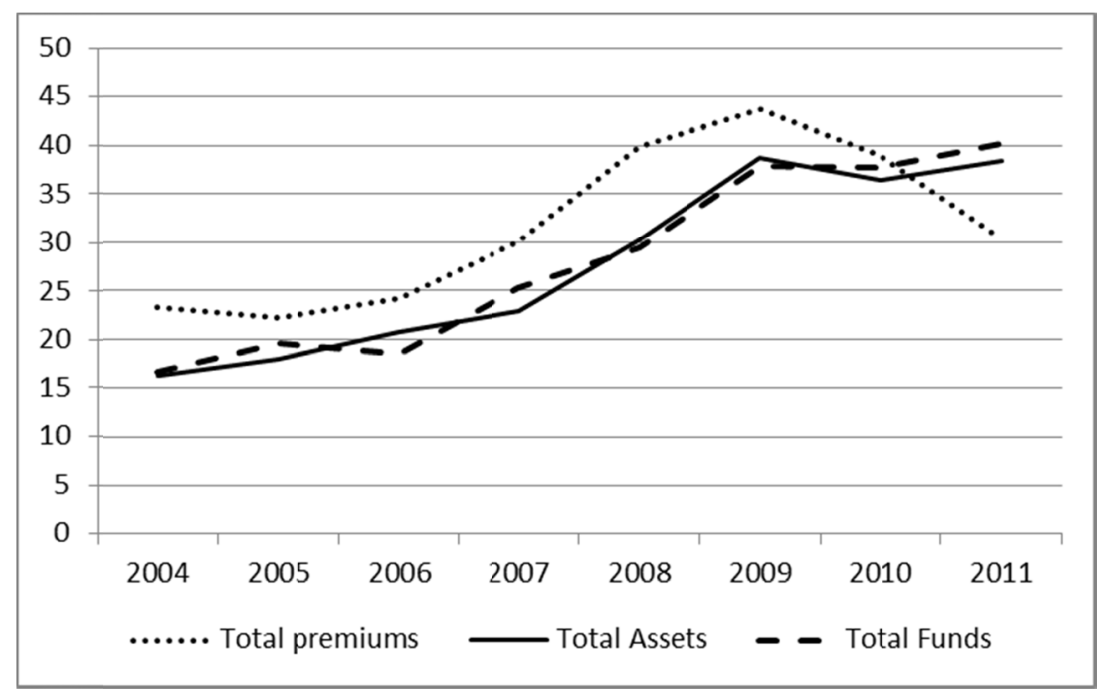

Figure 4. Market share of foreign pension companies (\%)

Source: www.treasury.gov.tr.

In Figure 4, improvement of market share of foreign companies in sector is shown according to premium amount, total asset and fund values in years. In the sense of premium amount, 23\% share of foreign companies in 2004 declined in small amount in 2005 but increased and reached the old level in later year. After 2006, it has increased in considerable rates until 2009 and reached the level of $44 \%$ which is the highest level until that time. However there was again a recession and in 2010 this rate was in similar course with the recession in sector declining to $39 \%$ and $30 \%$ in 2011 . In other words, while $25 \%$ of premiums belonged to foreign companies, this rate was $30 \%$ in 2011 . When the issue is regarded in the sense of total asset and fund values, $16 \%$ of share of foreign companies within assets and funds in 2004 decreased with a slight decline in 2010 and reached $40 \%$ level in 2011.

In 2010, market shares of foreign companies declined in the sense of three values though the greatest decline is observed at premium amount. This was followed by total asset and fund value respectively. As a result, market share of foreign companies is at $30 \%-40 \%$ level in the sense of these three indicators. During the analysis period, while the share of foreign company was more in premiums and less in funds in 2004; it is nearly the same in 2010 and totally opposite in 2011. Therefore, although there were changes in assets and fund values against domestic companies and on behalf of foreign companies, there were not important changes in the sense of premiums. This case results from the fact that domestic companies are relatively more successful in premium production. 


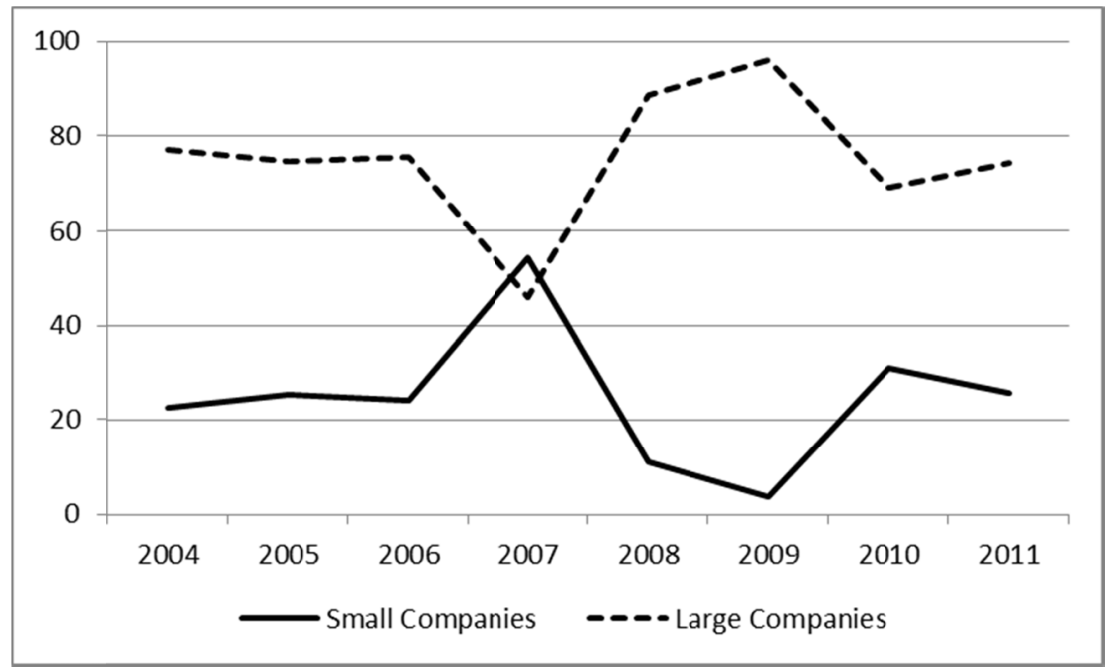

Figure 5. Market Share (\%) of pension companies in the sense of total net asset value of funds

Source: www.treasury.gov.tr.

In Figure 5, market share of pension companies in the sense of total net asset value of fund was given according to years. Average of annual fund values of sector was regarded in the categorization of companies. According to this, if the fund value of company is higher than average value company was regarded as large-scaled; if it is lower than average it was regarded as small-scaled. Market share of large-scaled and small-scaled companies were $80 \%$ and $20 \%$ respectively between 2004 and 2006, after this period market shares of companies began to approximate each other. In 2007, the gap has completely closed; even in this period market shares of small-scaled companies exceed those of large-scaled companies reaching 54\%. After 2007, market shares between companies began to increase on behalf of large-scaled companies and the difference reached the highest level in 2009. In 2011, dominance level of large-scaled pension companies within sector reach the level of the year 2004.

\section{Data and Method}

The analysis period of the study lasts for eight years from 2004 to 2011. Although it is the period when activities of private pension companies in Turkey started for the first time, the analysis started from 2004 instead of 2003 since it does not cover the whole period. Data about activities of private pension companies were obtained from reports about Insurance and Private Pension Activities in Turkey published in web site of Republic of Turkey Prime Ministry Undersecretariat of Treasury.

In the study a DEA model with four variables including two inputs and two outputs was used. The first input of the study was the number of employees representing the labor force. The second input variable was total assets representing capital. The first output variable is the total premiums collecting representing the income obtained by company. The other variable was the number of contracts to represent the number of participants. In this way DEA model with four variables was formed with input and outputs used in studies about insurance and PPS.

DEA is a non-parametric method using measurement of efficiency. The method was generated from Farell (1957) and later was popularized by Charnes et al. (1978).

DEA was used as efficiency measurement tool since it enables more than one input and output in measurement of efficiency for homogeneous samples, does not require functional relation between input-outputs and enables expression of input and outputs in different unit values.

DEA which is a nonparametric linear programming-based efficiency measurement model is a method which reflects more than one input-output relation and contrary to other methods reaches to solution with a few assumptions (Cooper, Seiford \& Zhu, 2004). The method enables measurement of relative efficiency of economic decision units in cases of comparing more than one input and outputs or those which were measured with different scales and have different units (Boussofiane et al., 1991). More than one input-output structure of method enables its application in various fields. This technique which aimed to evaluate efficiency of non-profit organization at first started to be used widespread in profit-oriented production and service sectors later (Donthu 
\& Yoo, 1998).

DEA determines relative efficiency of each unit by using observed inputs and outputs and calculating the rate of weighted outputs to weighted inputs. The most important reason in obtaining success in DEA is its being goal-oriented technique. This goal is to evaluate performances of decision units (Başkaya \& Akar, 2005).

\section{Results}

Findings obtained in the study are given in two titles. The first one is basic statistical properties of input and output variables used in the study, the second one are the findings obtained as a result of DEA.

\subsection{Basic Properties of Variables and Correlation Coefficient}

Before calculation of DEA, it is beneficial to analyze compatibility of input and output variables used in the study. Averages of variables and binary correlation coefficients are given in Table 2. According to table, average size of assets of pension companies sector is around 8 Billion TRY and premiums collected are 952 Million TRY. The number of employers working in the sector is 6,680 people and the number of contracts is 367,292.

Table 2. Average of input and output variables and correlation coefficients

\begin{tabular}{|c|c|c|c|c|c|}
\hline Variables & Average & $\begin{array}{c}\text { Total } \\
\text { Assets }\end{array}$ & $\begin{array}{l}\text { Number of } \\
\text { Employees }\end{array}$ & $\begin{array}{c}\text { Number of } \\
\text { Contracts }\end{array}$ & $\begin{array}{c}\text { Total } \\
\text { Premiums } \\
\end{array}$ \\
\hline Total Assets & $\begin{array}{c}\text { 7,946 Million TRY } \\
7.320\end{array}$ & 1 & & & \\
\hline Number of Employees & 6,680 People & $0.31^{* *}$ & 1 & & \\
\hline Number of Contracts & 367,292 & $0.78^{* *}$ & $0.30^{*}$ & 1 & \\
\hline Total Premiums & 952 Million TRY & $0.60^{* *}$ & $0.21^{*}$ & $0.40^{* *}$ & 1 \\
\hline
\end{tabular}

${ }^{*}$ and $^{* *}$ show $5 \%$ and $1 \%$ significance level respectively.

It is seen in Table 2 that correlation of input and output variables are respectively 0.31 and 0.40 . Correlation coefficients are positive and statistically significant. Moreover, it is also seen that correlation between input variables and output variables is positive and statistically significant. Therefore it is concluded that these four variables are in positive interaction with each other. In the light of these findings it can be said that correlation coefficients have acceptable quality in the sense of using input and output variables in DEA.

\subsection{Findings of Data Envelopment Analysis}

Here efficiency of private pension companies was calculated from 2004 to 2011 under the assumptions of both constant returns to scale (CRS) and variable returns to scale (VRS).

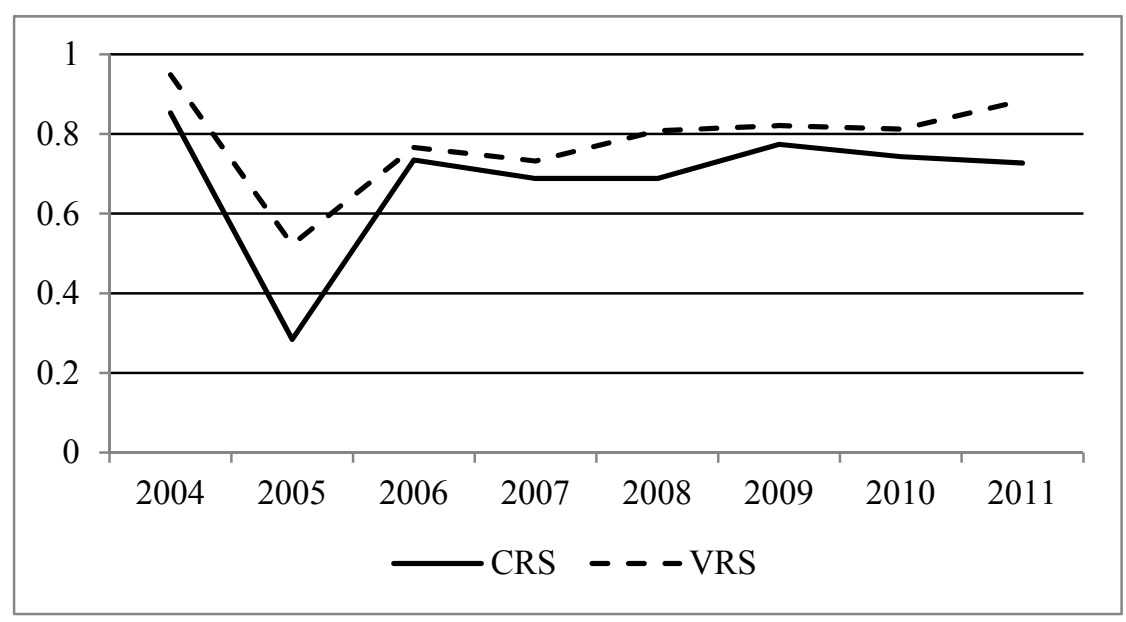

Figure 6. CRS and VRS efficiency of sector according to years

Average efficiency scores obtained according to years are given in Figure 6. It is observed that while CRS, total 
efficiency score, was at 0.85 level in 2004 it has dropped down to 0.28 level in 2005 . Then following year efficiency score reached 0.70 and then had a course around 0.70 . However in following years, it could not reach the level in 2004. Similar improvements can be stated for VRS assumption, in other words for technical efficiency score. Therefore, it can be said that efficiency decrease of sector experienced in 2005 could not be overcome.

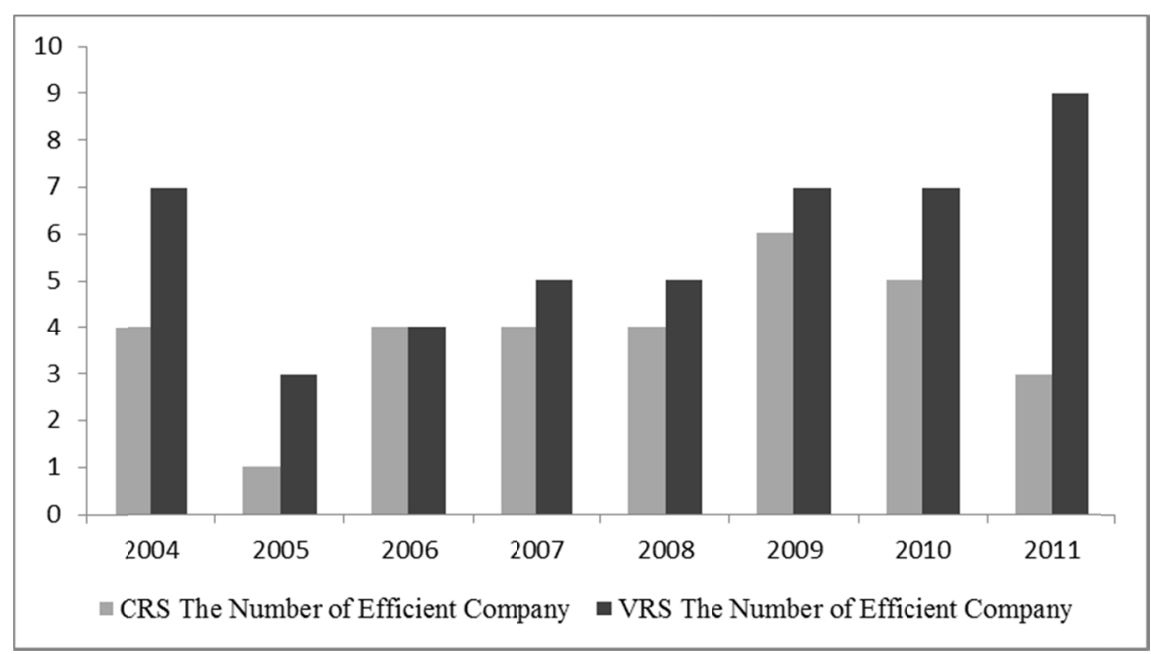

Figure 7. The number of efficient company according to CRS and VRS by years

In Figure 7, number of efficient companies according to CRS and VRS efficiency is presented in analysis period. When the figure is analyzed, the most attractive result is that apart from the year 2006, the number of active company according to CRS is lower than the number of companies according to VRS. In 2006; the number of efficient companies is the same. This situation points out that there is scale inefficiency in sector during periods apart from 2006. Therefore, there is an inefficiency based on scale in sector. This scale inefficiency can be compensated by changing scale size of inactive companies. In this way, the problem of scale inefficiency can be decreased.

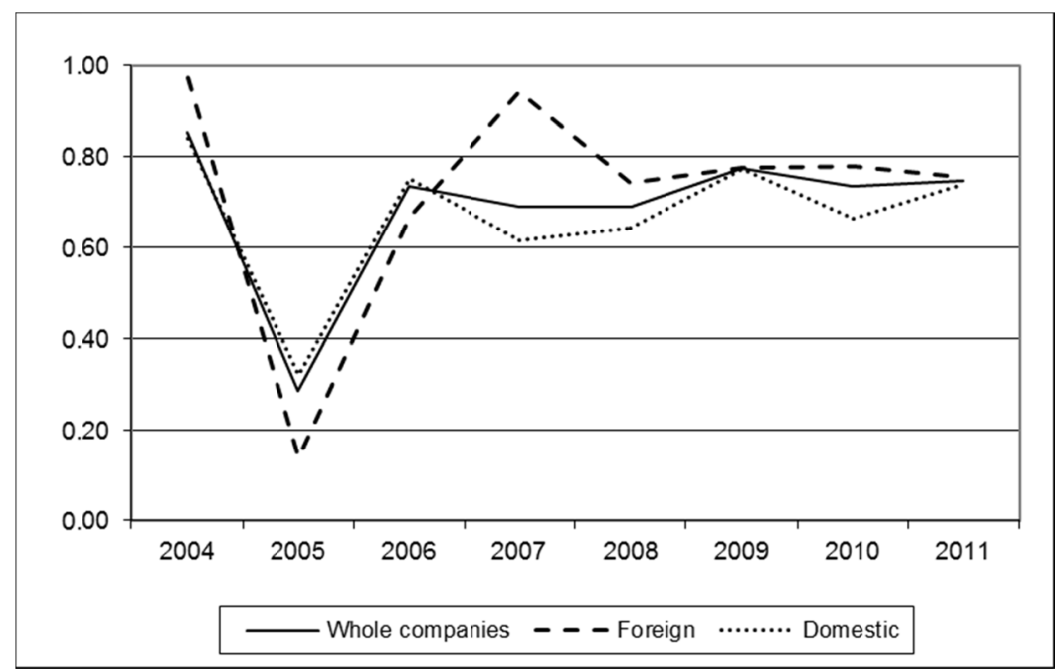

Figure 8. CRS efficiency of sector according to partnership structure

As it was mentioned before, it was observed that during analysis period domestic companies were purchased by foreign companies. In the study efficiency values of companies are included to the group in the related year they are included. In Figure 8, average of CRS, total efficiency score of foreign and domestic companies are given 
during analysis period.

It can be said that efficiency scores of foreign and domestic companies generally have a course parallel to sector average in general sense. The only distinctive exception of this is in the year 2007 when average efficiency score of foreign companies is higher than sector average. It is concluded here that in 2007, foreign companies produced more premium and contracts using labor and capital input compared to domestic companies.

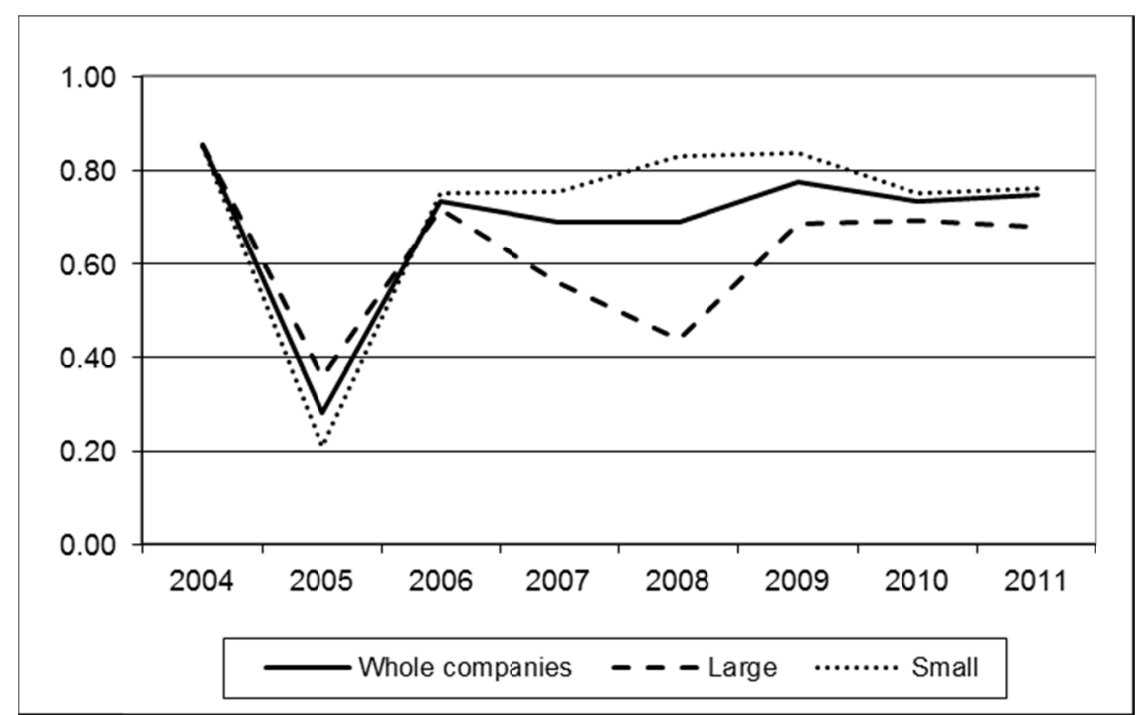

Figure 9. CRS efficiency of sector in the sense of total net asset value of funds

In Figure 9, there are average efficiency scores according to CRS assumption of pension companies sector and small and large-scaled companies. All the funds managed by companies are grouped into two as being small and large according to total net asset value of fund. Those which have more asset value compared to the average of related year were evaluated within large-scaled; others were evaluated in small-scaled company group. In this sense, efficiency score average of companies was calculated according to each year and efficiency score of each group was obtained.

It can be said that efficiency scores of small-scaled and large-scaled company groups between 2004 and 2006 have similar progress with the average of sector. In the following years, there were differences within these similarities. It is especially seen between 2007 and 2009 that efficiency score of both large-scaled and small-scaled company groups are distinctively different from the average of sector. Small-scaled company group has better efficiency while large-scaled company group has lower efficiency. This difference has continued though with relatively decrease in the following years. From this finding, it can be asserted that inefficiency within sector rather resulted from large-scaled companies after 2006. It can be said that the most important reason of this is global financial crisis. Therefore it is seen that global financial crisis causes increase of idle capacity in the input of large-scaled companies rather than small-scaled companies. This result shows that large-scaled companies adapt less and late to external changes compared to small-scaled companies.

\section{Discussion and Conclusion}

The scope of this study is measurement and evaluation of PPS efficiency in Turkey. In order to analyze PPS in more details companies were first of all groups as domestic-foreign and then as small-scaled and large-scaled and efficiency of groups were compared. It was put forward that efficiency scores of domestic and foreign companies were around the average of sector during analysis period except for 2007. It was found that efficiency of foreign companies were higher than efficiency of domestic companies in 2007. This finding shows that foreign pension companies are more active in their activities compared to domestic companies. The reason for foreign companies being more active is that their effect in sector increased through association and purchase, they obtain easier and cheaper resource from foreign countries and use innovative information and technology.

When the issue is regarded in the sense of large-scales companies, it was concluded that efficiency score of large and small-scaled companies was around the average of sector between 2004 and 2006 and efficiency score of both small and large-scaled companies were distinctively different from sector average after 2006. According to 
calculations, small-scaled companies have higher efficiency compared to large-scaled companies. It can be said that inefficiency within sector after 2006 results from large-scaled companies and the most important reason of this global financial crisis. In this way, there was more increase of idle capacity in the input of large-scaled companies. This results from the fact that large-scaled companies adapt late to external changes compared to small-scaled companies.

Another result of the study is that the number of active companies in the system was at lowest level in 2005 and increased continuously until 2011. Similarly; when the efficiency of system is analyzed according to years, CRS and VRS efficiency of PPS were at the lowest level in 2005 and then increased rapidly in the following years. The efficiency of system was in horizontal progress from 2006 and was around the level of 0.80 .

Effective management of PPS in Turkey is not only important for the partners, managers and participants of pension companies but also for creditors, state, financial and real sector which are the other stakeholders therefore for the whole economy. Resources brought together with the system are both an element of savings and financial resource of investments. In this property, it is compulsory to measure efficiency of companies and take measurements which increase efficiency for the development of country. Therefore, authorities as decision takers within and outside the firms should take measures in order to operate in optimal scale and to transform production factor effectively into production.

Finally, as a suggestion, next researches can analyze efficiency of private pension companies in Turkey by using DEA.

\section{References}

Banker, R. D., Charnes, A., \& Cooper, W. W. (1984). Some models for estimating technical and scale inefficiencies in data envelopment analysis. Management Science, 30(9), 1078-1092. http://dx.doi.org/10.1287/mnsc.30.9.1078

Barrientos, A., \& Boussofiane, A. (2005). How efficient are the pension funds managers in Chile? Revista de Economia Contemporânea, 9(2), 289-311. http://dx.doi.org/10.1590/S1415-98482005000200003

Barros, C. P., \& Garcia, M. T. M. (2006). Performance evaluation of pension funds management companies with data envelopment analysis. Risk Management and Insurance Review, 9(2), 165-188. http://dx.doi.org/10.1111/j.1540-6296.2006.00092.x

Barros, C. P., \& Garcia, M. T. M. (2007). Analyzing the Performance of pension funds industry with a stochastic cost frontier: A Portuguese case study. Geneva Papers on Insurance: Theory and Practice, 32, 190-210. http://dx.doi.org/10.1057/palgrave.gpp.2510126

Barros, C. P., Ferro, G., \& Romero, C. (2008). Technical efficiency and heterogeneity of Argentina pension funds. Technical University of Lisbon, School of Economics and Management, Working Paper No: 29.

Başkaya, Z., \& Akar, C. (2005). Sigorta şirketlerinin satış performanslarının veri zarflama analizi yöntemiyle belirlenmesi. Muğla Üniversitesi Sosyal Bilimler Enstitüsü Dergisi, 15, 37-51.

Boussofiane, A., Dyson, R., \& Rhodes, E. (1991). Applied DEA. European Journal of Operational Research, 2(6), 1-15. http://dx.doi.org/10.1016/0377-2217(91)90331-O

Charnes, A., Cooper, W. W., \& Rhodes, E. (1978). Measuring the efficiency of DMUs. European Journal of Operational Research, 2, 429-444. http://dx.doi.org/10.1016/0377-2217(78)90138-8

Cingi, S., \& Tarım, A. (2000). Türk banka sisteminde performans ölçümü: DEA, Malmquist, TFP endeksi uygulaması. Türk Bankalar Birliği Araşstırma Tebliğleri, 1.

Cooper, W. W., Seiford, L. M., \& Zhu, J. (2004). Data envelopment analysis: history, models, and interpretations. In W. W. Cooper, L. M. Seiford, \& J. Zhu (Eds.), handbook on data envelopment analysis. Springer Publishers.

Cummins, J. D., Tennyson, S., \& Weiss, M. A. (1999). Consolidation and efficiency in the U.S. life insurance industry. Journal of Banking and Finance, 23, 325-357. http://dx.doi.org/10.1016/S0378-4266(98)00089-2

Dekker, D., \& Post, T. (2001). A quasi-concave DEA model with an application for bank branch performance evaluation. European Journal of Operational Research, 132, 296-311. http://dx.doi.org/10.1016/S0377-2217(00)00153-3

Denizer, C., Dinç, M., \& Tarimcilar, M. (2000). Measuring banking efficiency in the pre- and post-liberalization environment: Evidence from the Turkish banking system. World Bank Research Working Papers, No.2476. 
Donthu, N., \& Yoo, B. (1998). Retail productivity assessment using data envelopment analysis. Journal of Retailing, 74(1), 89-105. http://dx.doi.org/10.1016/S0022-4359(99)80089-X

Farrell, M. J. (1957). The measurement of productive efficiency. Journal of the Royal Statistical Society, 120(3), 253-281. http://dx.doi.org/10.2307/2343100

Favero, C., \& Papi, L. (1995). Technical efficiency and scale efficiency in the Italian banking sector: A non-parametric approach. Applied Economics, 27, 385-95. http://dx.doi.org/10.1080/00036849500000123

Fukuyama, H. (1993). Technical and scale efficiency of Japanese commercial banks: A non-parametric approach. Applied Economics, 25, 1101-12. http://dx.doi.org/10.1080/00036849300000090

Golany, B., \& Storbeck, J. E. (1999). A data envelopment analysis of the operational efficiency of bank branches. Interfaces, 2(3), 14-26. http://dx.doi.org/10.1287/inte.29.3.14

Işık, I., Uysal, D., \& Meleke, U. (2003). Post-entry performance of de novo banks in Turkey. In 10th Annual Conference of the ERF. from http://www.erf.org.eg/tenthconf/financialmarkets_presented/ISIK_Uysal_Meleke .pdf

Kayalı, A. C. (2007). 2000-2006 döneminde Türkiye'de faaliyet gösteren sigorta şirketlerinin etkinlik değerlendirmesi. Celal Bayar Üniversitesi İ.I.B.F. Yönetim ve Ekonomi Dergisi, 14(2), 103-115.

Lovell, C. A. K., \& Pastor, J. T. (1997). Target setting: an application to a bank branch network. European Journal of Operational Research, 98, 290-299. http://dx.doi.org/10.1016/S0377-2217(96)00348-7

Mansoury, A., \& Salehi, M. (2011). Efficiency analysis and classification of bank by using data envelopment analysis (DEA) model: Evidence of Iranian bank. International Journal of the Physical Sciences, 6(13), 3205-3217.

Mercan, M., Reisman, A., Yolalan, R., \& Emel, A. B. (2003). The effect of scale and mode of ownership on the financial performance of Turkish banking sector: Result of a DEA-based analysis. Socio-Economic Planning Sciences, 37, 185-202. http://dx.doi.org/10.1016/S0038-0121(02)00045-9

OECD. (2012). Retrieved from http://www.oecd.org/daf/fin/private-pensions/PensionMarketsInFocus2012.pdf

Paradi, C. J., Yang, Z., \& Zhu, H. (2004). Assessing bank and bank branch performance: Modeling considerations and approaches. In W. W. Cooper, L. M. Seiford, \& J. Zhu (Eds.), handbook on data envelopment analysis. Springer Publishers.

Pension Monitoring Center. (2013). Retrieved from http://www.egm.org.tr/?sid=70

Porembski, M., Breitenstein, K., \& Alpar, P. (2005). Visualizing efficiency and reference relations in data envelopment analysis with an application to the branches of a German bank. Journal of Productivity Analysis, 23, 203-221. http://dx.doi.org/10.1007/s11123-005-1328-5

Rangan, N. R., Grabowski, H. A., \& Pasurka, C. (1988). The technical efficiency of U.S. banks. Economics Letters, 28, 169-75. http://dx.doi.org/10.1016/0165-1765(88)90109-7

Sherman, H., \& Ladino, G. (1995). Managing bank productivity using data envelopment analysis (DEA). Interfaces, 25, 60-73. http://dx.doi.org/10.1287/inte.25.2.60

Teresa, M., \& Garcia, M. (2010). Efficiency evaluation of the Portuguese pension funds management companies. Journal of International Financial Markets, Institutions \& Money, 20, 259-266. http://dx.doi.org/10.1016/j.intfin.2010.03.003

Vassiloglou, M., \& Giokas, D. (1990). A study of the relative efficiency of bank branches: An application of data envelopment analysis. Operation Research Society, 41, 591-597.

Wu, D., Yang, Z., Vela, S., \& Liang, L. (2007). Simultaneous analysis of production and investment performance of Canadian life and health insurance companies using data envelopment analysis. Computers \& Operations Research, 34(1), 180-198. http://dx.doi.org/10.1016/j.cor.2005.05.005

Yang, Z. (2006). A two-stage DEA model to evaluate the overall performance of Canadian life and health insurance companies and computer. Mathematical and Computer Modelling, 43(7-8), 910-919. http://dx.doi.org/10.1016/j.mcm.2005.12.01

Yue, P. (1992). Data envelopment analysis and commercial bank performance: A primer with applications to Missouri banks. The Federal Reserve Bank of St. Louis Review, 92(1), 31-45.

Zaim, O. (1995). The effect of financial liberalization on the efficiency of Turkish commercial banks. Applied 
Financial Economics, 5, 257-64. http://dx.doi.org/10.1080/758536876

\section{Copyrights}

Copyright for this article is retained by the author(s), with first publication rights granted to the journal.

This is an open-access article distributed under the terms and conditions of the Creative Commons Attribution license (http://creativecommons.org/licenses/by/3.0/). 